\title{
A port that could threaten marine life in England's Fal Estuary
}

\author{
Mark Deeble and Victoria Stone
}

The Fal Estuary, with its eelgrass meadows, its reef of red calcareous seaweeds and its mix of southern and northern species of marine life, contains a Voluntary Marine Reserve. As its name implies, such designation does not give it any legal protection. It is listed in The IUCN Invertebrate Red Data Book as a threatened community and is in immediate danger from a proposal to build a container port on the opposite shore.

Falmouth Bay, on the south Cornish coast at the western entrance to the English Channel, was considered by Clarke (1907) to contain the richest rocky shores in the British Isles and includes some of the finest sediment shores in Europe. In 1982 the Roseland Voluntary Marine Conservation Area was formed in an attempt to focus attention on the marine life of the $\mathrm{Fal}$ Estuary. The Voluntary Marine Reserve contains probably England's most extensive bed of calcareous red seaweed, maërl, and sublittoral meadows of eelgrass. The wildlife of the reserve is now threatened by plans to build a modern container port.

Falmouth's beaches, although still undeniably rich in species, have suffered from the pressures of tourism and pollution and no longer merit their former reputation. The extensive intertidal flats at Helford, once dominated by eelgrass Zostera marina with legions of the erect peacock worm Sabella pavonina and the slime-tube worm Myxicola infundibulum, have declined over the past decade - the few tubeworms now remaining are confined to the sublittoral.

Accompanying this decline has been a growing awareness of the importance of the marine life in 74 the Fal Estuary; today it is considered to be one of the richest areas in Britain and one of the cleanest estuaries in Europe.

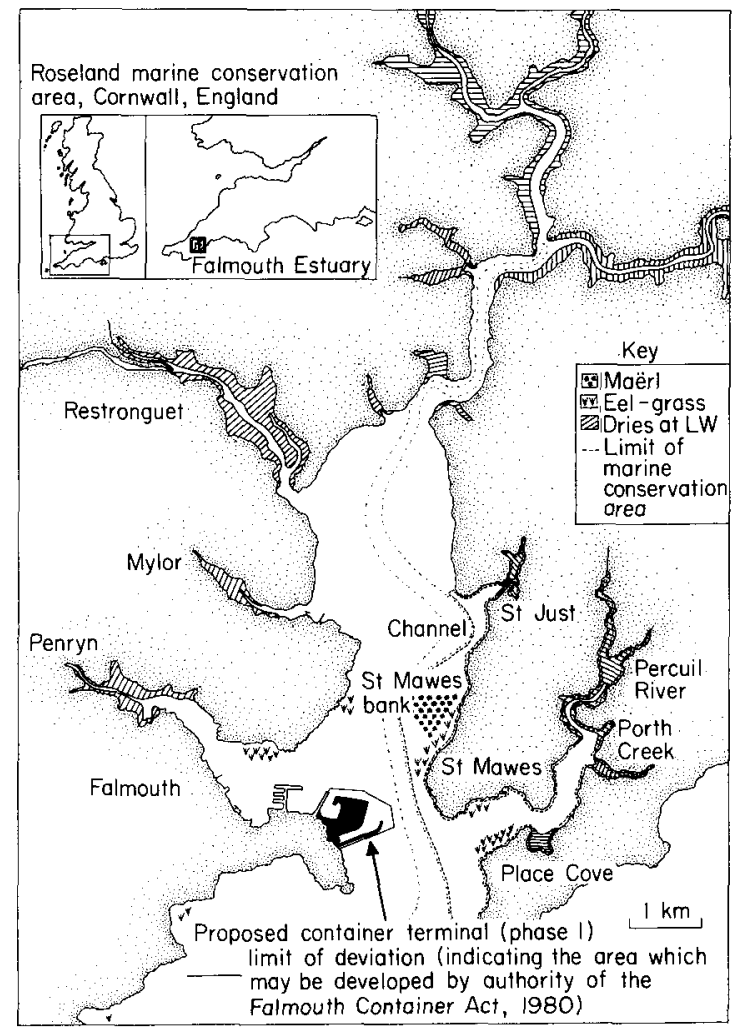

\section{Wildlife}

The estuary is a drowned river valley (ria) providing sheltered, almost fully marine conditions, with depths in excess of $30 \mathrm{~m}$ in the deep-water channel. Its location, on the south-west tip of

Oryx Vol 19 No 2 
England, allies it with the west coast of Ireland, South Wales and Brittany, all of which lie within the same biogeographic zone (Ekman, 1953). The zone falls between southern (lusitanian) and northern (boreal) biogeographic regions and consequently elements from each result in a high species diversity in this intermediate zone. For example, the giant goby Gobius cobitis, a southern species, coexists with northern species, such as Yarrell's blenny Chirolophis ascanii.

A wide range of habitats is extended by the presence of eelgrass meadows and a reef of living maërl, comprising two species of red algae, Phymatolithon calcareum and Lithothamnium coralloides. Maërl grows as rhodoliths-brittle, pink, coalescing nodules, which are up to 40 years old and $10 \mathrm{~cm}$ in diameter. The nodules are unattached, the maërl forming a shallow (5-12 m water depth) sublittoral reef over about 3 ha of $\mathrm{St}$ Mawes bank. The open matrix of the rhodoliths, covering the seabed in hundreds of thousands to a depth of $20 \mathrm{~cm}$, provides an unusual and distinct habitat harbouring a community of molluscs, anemones, worms and decapod crustaceans. Densities of long-clawed porcelain crabs Psidia longicomis, squat lobsters Galathea squamifera and prawns Athanas nitescens may exceed 100 per sq m. Over 120 species of seaweed have been identified from the reef-many new to the British Isles, for example Solieria chordalis and Cruoria cruoriaeformis (Farnham and Jephson, 1977; Farnham, 1980).

Inshore, to the east of the maërl and also to the south of St Mawes, meadows of eelgrass grow in shallow water $(0-5 \mathrm{~m})$. Eelgrass, one of the few flowering plants that is truly marine, grows as a dense sward and is an important nursery for young fish and a habitat with its own distinct community of molluscs, tubeworms and burrowing anemones, for example Peachia hastata. In spring, fifteen-spined sticklebacks Spinachia spinachia build their fist-sized nests high amongst eelgrass leaves and in early summer, when the plants flower, cuttlefish Sepia officinalis lay clusters of black eggs, known as 'sea raisins', entwined among the stems. In mid-summer, large numbers of sea hares Aplysia punctata, a large seaslug growing to $20 \mathrm{~cm}$ in length, migrate to the eelgrass from deeper water in order to spawn. Port threat in Fal Estuary

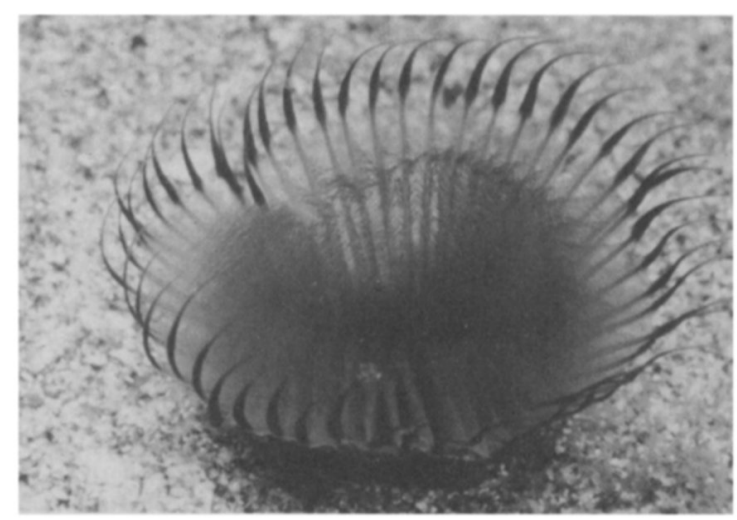

The slimetube worm Myxicola infundibulum is an important member of maërl and eelgrass communities (Victoria Stone).

Sea hares are hermaphrodites and often copulate in long chains that meander slowly through the meadows, each animal acting as a male to the one in front and a female to the one behind. Occasionally the two ends of a chain join, enabling each member to fulfil a dual sexual function.

Place Cove, opposite St Mawes, is a focal site for long-term research by the Marine Biological Association, UK. Lagoon-like conditions support a diverse hard and soft substratum community, including a shallow-water bed of the smooth venus Callista chione - a Mediterranean species at its northernmost limit. The Duchy of Cornwall maintains commercial beds of the native oyster Ostrea edulis further up Percuil River, where the sublittoral fauna is dominated by the trumpet anemone Aiptasia mutabilis, a southern species, and the solitary seasquirt Ascidiella aspersa.

Surrounding creeks maintain large populations of tubeworms, for example the sandmason Lanice

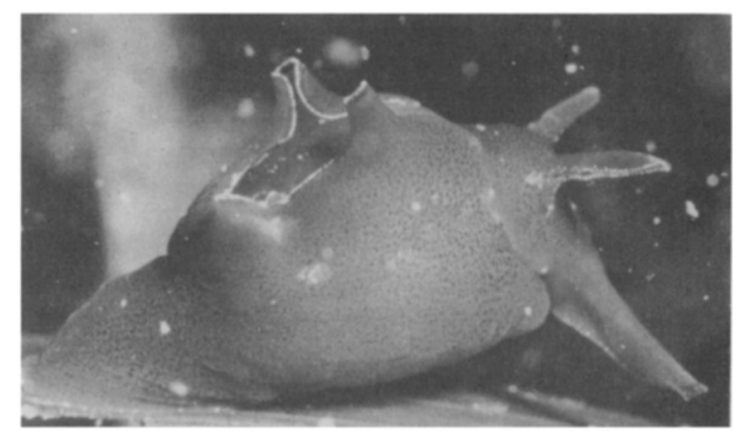

A young sea-hare Aplysia punctata on eelgrass Zostera marina (Mark Deeble/Victoria Stone) 
conchilega, and the daisy anemone Cereus pedunculatus reaches densities of 1000 per sq $\mathrm{m}$ in places (Burrows, 1984a). The creeks support large numbers of overwintering waders and provide a safe refuge for the otter Lutra lutra (Turk, 1982)-a threatened species on the decline in the south due to habitat destruction.

\section{Conservation}

The declaration of the Roseland Marine Conservation Area (1982) sought to publicise the importance and vulnerability of the communities associated with St Mawes bank and the St Mawes inlet. The area is a Voluntary Marine Reserve with no statutory powers, monitored by the Roseland Research Group, which includes representatives from the University of Exeter, the Cornwall Trust for Nature Conservation, the Marine Biological Association, UK, the Marine Conservation Society and the Nature Conservancy Council (NCC). The reserve is listed as a threatened community' in The IUCN Invertebrate Red Data Book (Wells, Pyle and Collins, 1983) and the St Mawes inlet has been designated by the NCC as a Primary Site of National Marine Biological Importance (Bishop and Holme, 1980). Land adjacent to St Mawes bank is owned by the National Trust and the Conservation Area lies within an Area of Outstanding Natural Beautycontaining several special sites scheduled by Cornwall County Council Planning Department.

The purpose of the reserve is primarily educational and a code of conduct (1984) detailing the importance of the reserve with appropriate

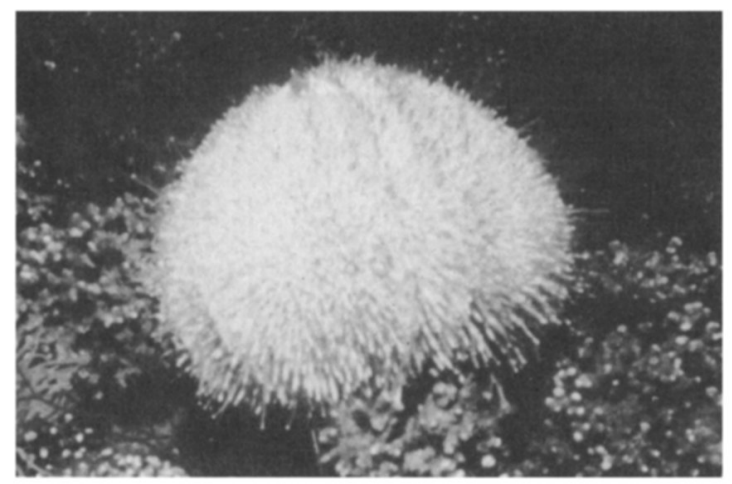

The edible sea-urchin Echinus esculentus grazes epiphytes from rhodoliths of maërl Phymatolithon calcareum (Victoria Stone/Mark Deeble).

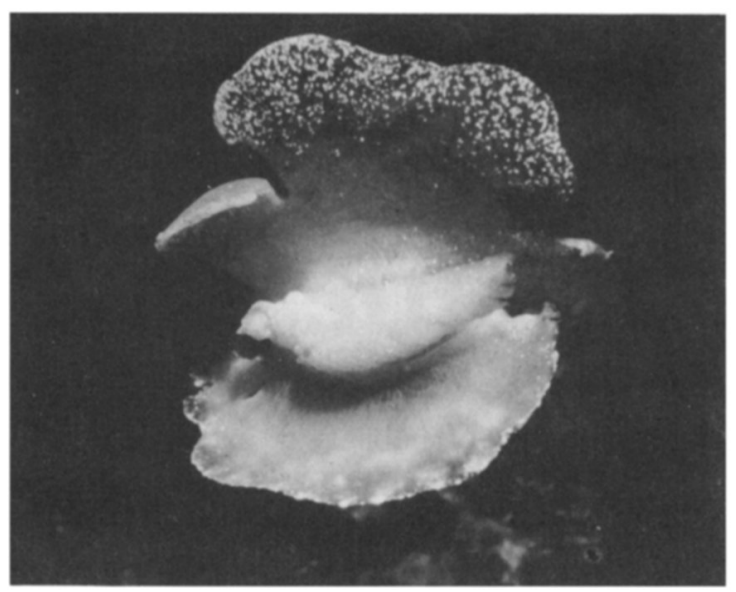

The opisthobranch Pleurobranchus membranaceus swims upside down and is a specialist feeder on solitary sea-squirts (Victoria Stone).

conservation recommendations is circulated to those who use the area.

\section{Threats}

Activities such as bait digging or winkle Littorina littorea and queenie Chlamys sp. collecting are on a small scale, but have considerable local impact. Bait digging, for ragworms Nereis diversicolor and Nereis virens, disturbs anaerobic sediments resulting in a reduced faunal diversity. Trench transects dug by over-enthusiastic educational groups can produce similar results and, if neither are back-filled, scouring by successive tides results in habitat erosion. Winkle and queenie gathering on boulder shores is not intrinsically destructive, but, if rocks are not replaced, the seaweeds and attached animals die within days. It can take several years for a barren rock to be recolonised and such thoughtless collecting can ruin a boulder shore in an afternoon.

The reef of maërl is the most endangered community within the estuary. Anchors crush the delicate rhodoliths and significant areas are destroyed by the scouring actions of the heavy ground chains of buoys delimiting a water-ski area. A positive aspect of the ski area, however, is that it acts as a partial exclusion zone for other activities.

Fishing on the maërl reef is negligible as the natural oyster beds, dredged under sail during the

Oryx Vol 19 No 2 
winter months, are confined to the northern banks. Gill-netters avoid the maërl, as it can take days to remove the rhodoliths from monofilament nets, and trawling is mainly confined to the edges of the channel.

Two companies are licensed to extract dead maërl from the estuary-the bleached white 'skeleton' breaks down to produce a fine sand of almost pure calcium carbonate which is dredged and marketed as a soil conditioner. It is thought unlikely that limited commercial extraction of deposits of dead maërl will significantly affect the productivity of the estuary (Hardiman et al., 1976).

\section{Container port}

The main threat to the unique and diverse assemblage of communities within the conservation area is the proposal to build a modern container complex on the western shore, south of the existing docks.

Of particular concern is the Government's intention to repeal Section 9 of the Harbour Act, 1964, which is to be given immediate effect by the revoking of the Control of Harbour Development Orders. This means that harbour developments in excess of a certain financial threshold (currently $£ 3$ million) no longer require the sanction of the Department of Transport. It was the Department's decision to withhold authorisation that prevented the building of the container port when first proposed in 1971, and again in 1982. The container port, to be operational by 1987 if construction begins by the end of 1984 , involves the reclamation of 80 acres ( 32 ha) of land and the construction of a 700-m breakwater, which will effectively halve the mouth of the estuary.

The survival of the maërl depends on a combination of sheltered, well-lit, fully marine conditions with only gentle currents to prevent the rhodoliths becoming clogged with silt. Threats to the maërl are fourfold (Burrows, 1984b). The reclamation work and increase in tidal flow velocity at the mouth of the estuary, following construction of the breakwater, would increase the turbidity and reduce the light available to the maërl for photosynthesis. An increase in flow rate could scour the bank or wash the unattached rhodoliths into the channel. If flushing time is increased there would be a concomitant increase in pollutant retention time and possible changes in salinity. The northern banks, particularly around Restronguet, contain sediments rich in zinc, copper and cadmium (Bryan and Gibbs, 1983), a legacy of a former extensive mining industry. Mobilisation of the toxic sediments by changes in current direction or velocity could result in their deposition on unpolluted eastern banks with disastrous consequences for the communities involved.

Conservation hopes rest on the results of a hydrographic survey commissioned from Hydraulic Research Ltd, Wallingford by Falmouth Container Terminal Co. Ltd. However, the survey is likely to remain a 'desk' study unless adverse findings indicate the requirement for a more expensive survey involving hydraulic tests on a scale model. The survey is expected to concentrate on the safety to shipping and navigational aspects of the construction and there is currently no requirement or provision to assess the environmental impact of the scheme on the marine life of the estuary.

Before work begins, five consents are required under the Falmouth Container Terminal Act, 1971. The Secretary of State for Trade must be satisfied that the port will not pose an obstruction or danger to navigation. Falmouth Harbour

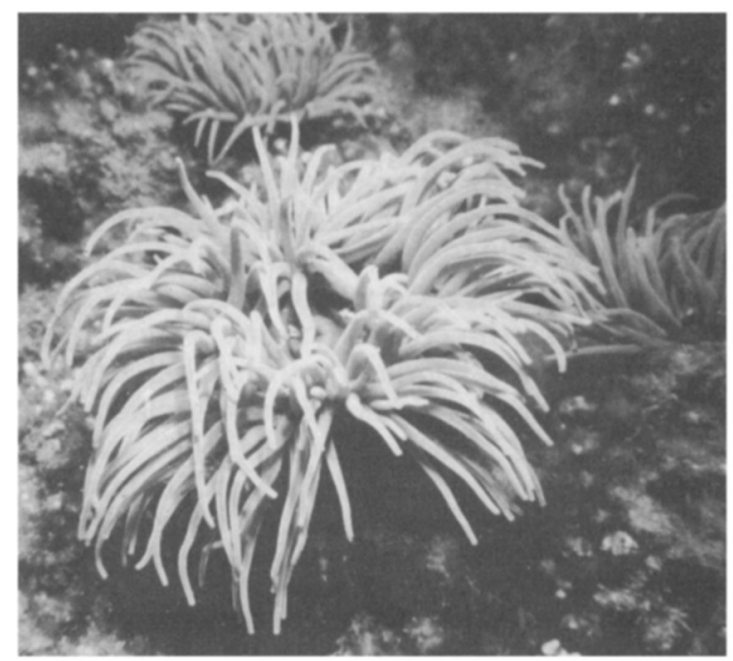

Maërl supports large numbers of the snakelocks anemone Anemonia viridis (Victoria Stone). 
Commissioners and Falmouth Docks and Engineering Co. must grant permission under Section 28 of the 1971 Act. The Commissioners have openly backed the scheme from its conception and although the Docks are due to be sold there is no reason why there should not be full co-operation between the two industries or amalgamation under a single ownership. The Ministry of Agriculture, Fisheries and Food is required to approve the reclamation project under the Dumping at Sea Act, 1974, while Carrick District Council must approve the detailed plans. The Environmental Health Department of the Council is conducting its own long-term environmental study to assess and monitor the quality of the water in the estuary. The Duchy of Cornwall, and, more recently, Carrick District Council, are believed to be the most concerned, of all the consenting bodies, about the possible environmental implications of the scheme. The existence of the oyster fishery and the Duchy-owned beds in Percuil, a traditional fishery employing about 50 people, could be jeopardised by the development and it is likely that the Duchy and the Council will require a detailed environmental survey.

The venture is, at best, regarded as 'speculative' (Grey, 1984) by the trade press and it has received a hostile reaction from struggling British container ports-dockers at Liverpool have threatened a national dock-workers strike if construction begins. Falmouth Container Terminal Co. remains unworried. The company is primarily concerned with the construction scheme-it is a subsidiary of the civil engineering giant, Balfour Beatty and, once built, at a cost of $£ 70$ million, the port will be leased to Felixstowe Dock and Railway Co. (Slater, 1982). If consents are given and the land reclaimed, but not developed as a port, then the company gains 80 acres (32 ha) of prime building land on one of the finest parts of coastline in Britain (current reclamation costs about $£ 120,000$ /acre).

\section{Recommendations}

The University of Exeter has joined Roseland Research Group and local conservationists in calling for a detailed long-term survey of the estuary. This should include the hydraulic testing of a scale model, to predict accurately the 78 changes in the hydrographic character of the estuary following the construction of the container port. The survey should investigate the possible changes in direction and velocity of tidal flow, scouring, rates of sedimentation, salinity, and turbidity, which would enable an independent organisation to assess the threats to the marine life of the estuary.

The bodies whose consent is required should assure themselves as to the need for the container port, and, if the development is to proceed, a plan with the minimum environmental impact should be selected.

\section{References}

Bishop, G.M. and Holme, N.A. 1980. The sediment shores of Great Britain: an assessment of their conservation value. Final Rep., Part 1. Survey of the littoral zone of Great Britain. SMBA/MBA, Intertidal Survey Unit.

Bryan, G.W. and Gibbs, P.E. 1983. Heavy metals in the Fal Estuary, Cornwall: a study of long-term contamination by mining waste and its effects on estuarine organisms. Occ. Publ. Mar. biol. Ass. No. 2. 18-19.

Burrows, R. 1984a. Wildife of the. Fal Estuary. Harbour Books, Dartmouth.

Burrows, R. 1984b. Proposed Falmouth container port. The Roseland Research Group's comments on the proposed developments at Falmouth. Unpub. report.

Clarke, J. 1907. The excursion of Gyllynguase Beach. Rep. R. Cornwall polytech. Soc. 25, 47-51.

Ekman, S. 1953. Zoogeography of the Sea, pp. 80-120. Sidgwick and Jackson, London.

Farnham, W.F. 1980. Studies on aliens in the marine flora of southern England. In The Shore Environment, vol. 2. Ecosystems, pp. 875-916 (Eds J.H. Price, D.E.G. Irvine and W.F. Farnham). Academic Press, London.

Farnham, W.F. and Jephson, N.A. 1977. A survey of the maërl beds of Falmouth (Cornwall). Brit. Phycol. J. 12, 119.

Grey, R.S.M. 1984. Going west. Fairplay International (Shipping Weekly). 19 April, 3.

Hardiman, P.A., Rolfe, M.S. and White, 1.C. 1976. Lithothamnium studies off the south west coast of England. International Council for Exploration of the Sea, Shellfish and Benthos Committee.

Slater, P. 1982. The proposed Falmouth container terminal Unpub. report.

Turk, S.M. 1982. Consultation paper re proposal to create a marine reserve in Carrick roads, Falmouth, to include St. Mawes Bank and St. Mawes inlet with adjacent areas. Preliminary draft.

Wells, S.M., Pyle, R.M. and Collins, N.M. 1983. The IUCN Invertebrate Red Data Book. IUCN, Gland, Switzerland.

Mark Deeble, Department of Zoology, University College of Swansea, Singleton Park, Swansea SA2 8PP, Wales. Victoria Stone, Trescobeas Manor, Falmouth, Cornwall TR11 $4 J B, U K$

Oryx Vol 19 No 2 